\title{
Grazing by large river zooplankton: a key to summer potamoplankton decline? The case of the Meuse and Moselle rivers in 1994 and 1995
}

\author{
Véronique Gosselain ${ }^{1}$, Jean-Pierre Descy ${ }^{1}$, Laurent Viroux ${ }^{1}$, Célia Joaquim-Justo ${ }^{2}$, \\ Astrid Hammer ${ }^{3}$, Arnaud Métens ${ }^{1} \&$ Sabine Schweitzer ${ }^{4}$ \\ ${ }^{1}$ Laboratory of Freshwater Ecology (LFE), Facultés Universitaires Notre-Dame de la Paix, rue de Bruxelles, 61, \\ 5000 Namur, Belgium \\ ${ }^{2}$ Laboratoire d'Ecotoxicologie, Institut de Zoologie, Université de Liège, Quai Van Beneden, 22, 4020 Liège, \\ Belgium \\ ${ }^{3}$ Erasmus student at LFE, from the University of Rostock, Germany \\ ${ }^{4}$ Centre de Recherches Ecologiques de l'Université de Metz, France
}

Key words: potamoplankton, plankton interactions, in situ grazing, European rivers

\begin{abstract}
To explain summer declines in phytoplankton biomass in large rivers, we compared the effect of zooplankton grazing on the planktonic algae of two large European rivers, the Meuse and the Moselle. In situ grazing was measured during two years (1994 and 1995), using the Haney method. Total zooplankton community filtration rates recorded in the river Meuse ranged between 1 and 32\% of the water volume filtered per day. A drastic algal decline was observed early July both years and may be explained by high densities of a rotifer-dominated zooplankton community (500-700 ind. $1^{-1}$ ) with more than 75\% of Brachionus calyciflorus. During the summer period in 1994, when grazing was over $20 \%$, edible algal biomass was controlled by a diversified rotifer community (up to 2500 ind. $1^{-1}$ ), while a non-edible algal assemblage developed. In contrast, phytoplankton biomass remained comparatively low in the Moselle throughout the low-flow period, as did zooplankton numbers during most of this time (fewer than 200 ind. $1^{-1}$ during the summer period). The proportion of crustaceans in this zooplankton was rather higher than in the Meuse, and they dominated at times, in biomass as well as in numbers. Nevertheless, measured in situ grazing rates $(1-15 \%)$ could not explain the low summer algal biomass, even if low filtration rates may at times represent a significant carbon loss for phytoplankton, when and where net algal production was low. As a conclusion, the role of phytoplankton - zooplankton interactions in controlling algal biomass in large rivers is discussed.
\end{abstract}

\section{Introduction}

Summer declines of potamoplankton have been reported from several large rivers, including the Meuse (Gosselain et al., 1994; Gosselain et al., 1998), the Moselle (Descy \& Willems, 1991; Descy, 1993), the Rhine (de Ruyter van Steveninck et al., 1992; Admiraal et al., 1994), the Spree (Köhler, 1995) and the Seine (Garnier et al., 1995). These declines may be of short duration, as in the River Meuse, or span many weeks and affect long river sectors (as in the Moselle). Longitudinal (downstream) declines may also be superimposed, as in the Rhine (de Ruyter van Steveninck et al., 1992;
Admiraal et al., 1994), the Spree (Köhler, 1995) and the Seine (Garnier et al., 1995). In some cases, a low summer phytoplankton biomass may result in water quality problems, as large rivers usually have an important organic matter loading; along polluted stretches, the balance of the oxygen is so delicate that a decrease of planktonic production may fail to offset critical oxygen deficits.

As stated by Reynolds \& Descy (1996) in their recent synthesis on phytoplankton in large rivers, longitudinal declines of producer biomass can result from changes in physical conditions along the river course. Net algal production is related to the ratio between the 
river depth and its euphotic layer, so that a decrease in chlorophyll $\mathbf{a}$ is expected in the downstream sections of large rivers, as a consequence of increasing turbidity and depth. This is in agreement with general concepts on river function (e.g. Vannote et al., 1980) which predict a trend toward heterotrophy for the high order sections of long watercourses. Furthermore, in relation with temporal summer declines, Reynolds \& Descy (1996) pointed out that conditions apparently optimal (summer temperatures, more sunlight over a longer day, less turbidity, slower downstream travel) do not necessarily coincide with the highest net algal increase. In fact, 'these are the conditions under which the potamoplankton dynamics become very sensitive to cell-specific loss processes, particularly where zooplankton development is favoured or where shallow water and accelerated sinking rates contribute to enhanced losses to sedimentation' (Reynolds \& Descy, op. cit.).

A second approach to the investigation of algal declines in large rivers is to consider biotic interactions, namely zooplankton feeding on algal biomass. In a previous publication dealing with observations in the River Meuse in 1992 (Gosselain et al., 1994), we hypothesised that this process may have a significant influence on the potamoplankton community. According to our deliberations on zooplankton and mathematical simulations, the phytoplankton summer variations could be explained as a combination of low growth rates and losses from zooplankton grazing and sedimentation. Combining grazing measurements from the Meuse, assembled over three years (1994-1996; Gosselain et al., 1998), with measured grazing rates by the rotifer-dominated communities, we found loss rates between 1 and $113 \%$. However, this grazing pressure resulted from small zooplankton feeding, affecting algae only in the size range $<20 \mu \mathrm{m}$; this seems to explain why larger phytoplankton units became dominant in the summer assemblage. In one of the few studies conducted on plankton interactions in rivers, de Ruyter van Steveninck et al. (1992) demonstrated the possible role of biotic interactions within the planktonic community in the Dutch section of the River Rhine. They estimated zooplankton filtration rates in the range $0.07-0.181[\mathrm{ZooC}]^{-1} \mathrm{~h}^{-1}$ or $0.01-0.18$ $\mathrm{d}^{-1}$. However, depending on the season, only 2.3 to $28 \%$ of the algal biomass loss could be explained by this level of grazing. Garnier et al. (1995) calculated grazing fluxes in the River Seine to be in the range 200$450 \mathrm{mg} \mathrm{C} \mathrm{m}^{-2} \mathrm{~d}^{-1}$, which was estimated to represent between 20 and $50 \%$ of phytoplankton growth (and occasionally up to $75 \%$ for diatoms or chlorophytes). In the River Spree, biotic interactions have also been strongly implicated but, going downriver, zooplankton rapidly declined and could only account for few algal losses (Köhler, 1995).

Besides a possible effect of zooplankton grazing on phytoplankton biomass, many reports emphasise the consequences of filtration by benthic filter feeders, especially the zebra mussel Dreissena polymorpha Pallas. In the River Rhine, increasing populations of the zebra mussel have been suspected to have modified food web structure, along with the amphipod Corophium curvispinum Sars (Admiraal et al., 1994). Similarly, large numbers of molluscs (mainly Unio tumidus Phil. and Anodonta anatina L.) have been recorded in parts of the lower Spree, arguing for an effective grazing by benthic filter feeders (Köhler, 1995). Some impact of zoobenthos on phytoplankton summer declines have also been suggested by Garnier et al. (1995) as a possible explanation for enhanced phytoplankton mortality in the River Seine.

In this respect, it is interesting to report the impact of new settled zoobenthos, in particular of the zebra mussel $D$. polymorpha, in some American large rivers and lakes. In the River Seneca, dramatic changes in water quality, particularly on the oxygen resources, have been brought about by zebra-mussel infestation (Effler et al., 1996). Recorded filtering rates for settled bivalves range from 100 to $400 \mathrm{ml}$ ind. ${ }^{-1} \mathrm{~h}^{-1}$ (Sprung, 1995) for large individuals ( $20 \mathrm{~mm}$ shell length) and higher values have also been reported (e.g. MacIsaac et al., 1992). Filtering rates are biomass-dependent and a strong temperature effect has been reported, with a maximum recorded at $20{ }^{\circ} \mathrm{C}$ (Aldridge et al., 1995). According to Sprung \& Rose (1988), adult zebra mussels prefer food in the $15-40 \mu \mathrm{m}$ size range but they stressed also that the inhaling siphon aperture size seems to enable the mollusc to ingest all algal size units. Furthermore, MacIsaac et al. (1995) reported ingestion of microzooplankton, probably at a rate approaching values for phytoplankton food. Effler et al. (1996) also showed that low dissolved oxygen was related to a high respiration demand from the zoobenthos. Böhme (1994) suggested that oxygen consumption in large rivers might be partly dependent on benthic community respiration.

The purpose of this paper is to assess the effect of zooplankton grazing on the planktonic algae of two large rivers, the Meuse and Moselle rivers, mainly through in situ zooplankton grazing measurements. We 


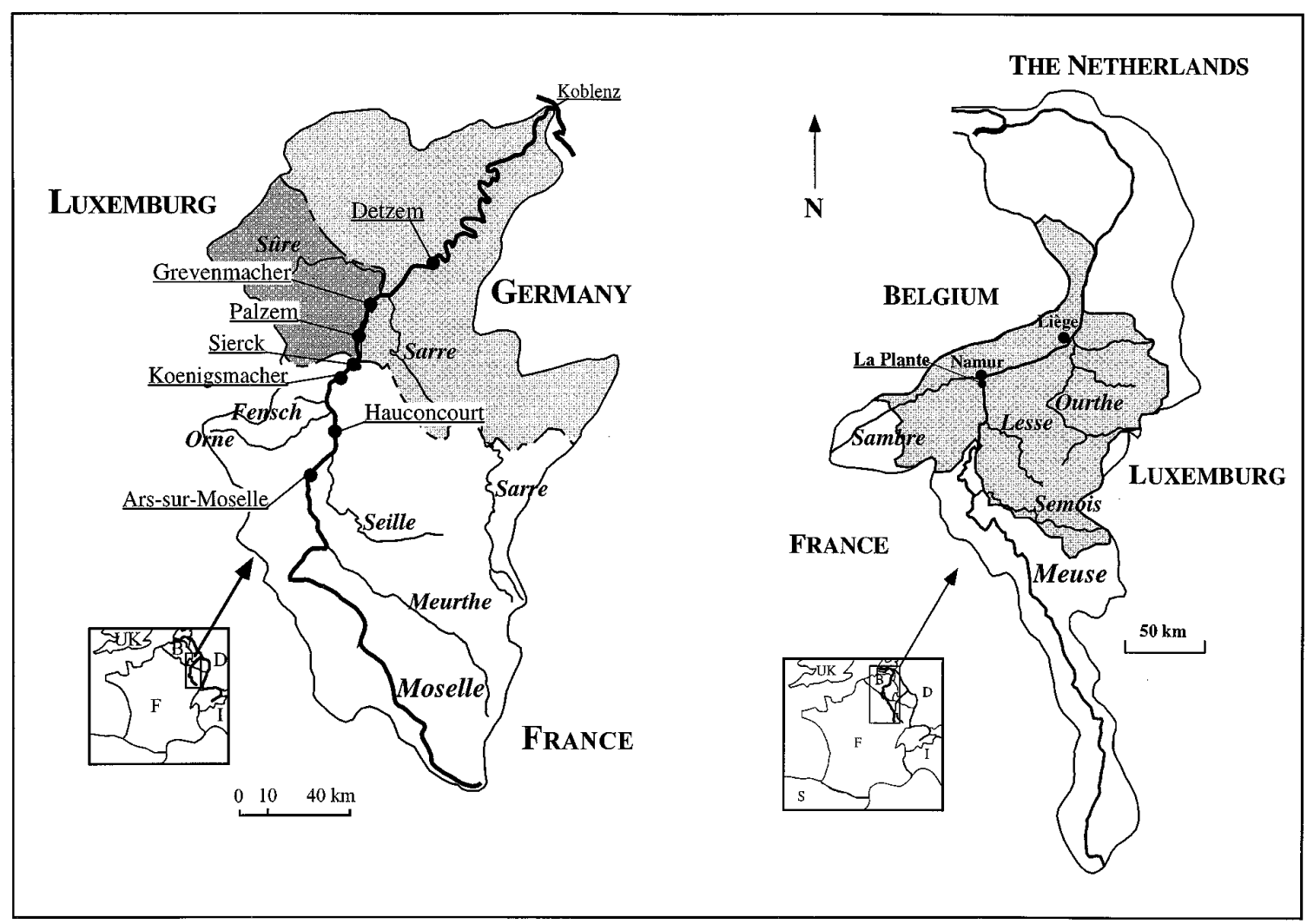

Figure 1. Map of the Meuse and Moselle rivers basins. Main tributaries are reported in italic letters and studied stations are underlined.

present hereafter the data from two years of investigations, 1994 and 1995, in both rivers.

\section{Description of the studied sites}

The Meuse and Moselle rivers both rise in north-east of France (Figure 1). The Meuse flows through Belgium and The Netherlands, where it meets the lower Rhine, forming the Dutch Delta, which opens in the North Sea. Its total length is $885 \mathrm{~km}$ and its catchment area is about $36,000 \mathrm{~km}^{2}, 40 \%$ of it being within Belgian territory and where the river has been regulated for navigation with weirs and locks. The Moselle is a major tributary of the Rhine: its total length is $535 \mathrm{~km}$ and its catchment area about $28,000 \mathrm{~km}^{2}$. The river has been partly canalised but some natural stretches have been maintained, so that the river flows alternately through deep, slow-flowing reaches and wild, shallow, sometimes meandering reaches.

Both are nutrient-rich, eutrophic rivers (see annex). Nevertheless, the River Moselle has more alkaline and more electrically conductive waters (Descy \& Willems, 1991).

Phytoplankton composition is similar in the two rivers, with centric diatoms dominating throughout the plankton growth season. Nevertheless, the Moselle carries some typically halophilous or euryhaline taxa, originating from the Meurthe and Seille rivers (Descy \& Willems, 1991), among them Skeletonema potamos (Weber) Hasle and S. subsalsum (Cleve-Euler) Bethge. It should be noted that $S$. potamos has been recorded recently in the Meuse as well, where it now sometimes accounts for half the phytoplankton numbers. Green algae seem to achieve higher biomass in the Meuse. The zooplankton is dominated by rotifers in both rivers but microcrustacean biomass sometimes exceeds rotifer biomass in the Moselle, during the summer months.

The main study site on the Meuse, 'La Plante', is located at $537 \mathrm{~km}$ from the source. At this site, the mean depth is $3.95 \mathrm{~m}$ and the mean width is $100 \mathrm{~m}$. Seven stations along the Moselle, spanning $140 \mathrm{~km}$, 
were sampled, viz.: Ars-sur-Moselle (river km 245), upstream from the city of Metz; Hauconcourt (Argancy dam, km 269), downstream of the city of Metz, the confluence with the river Seille and the outlet of the cooling basin of the power plant of La Maxe; Koenigsmacker ( $k m$ 297), upstream from the outlet from the nuclear power plant of Cattenom; Sierck (km 310); Palzem (km 323) and Grevenmacher (km 340) in Luxembourg; Detzem (km 386), in Germany. The different sampling designs owe to the quite different study objectives. The sampling strategy is related to the purpose of the studies: in the River Meuse, we sampled one station through time; longitudinal differences were the focus of research on the Moselle, where in situ determinations were also undertaken in 1994 and 1995.

\section{Materials and methods}

\section{Sampling and data acquisition}

So far as it was possible, the Meuse was sampled each week during the season of potamoplankton development; grazing measurements were made each fortnight. The Moselle was sampled at fortnightly intervals; in situ measurements of grazing and primary production were made on five occasions (1-4 August 1994; 30 May-1 June, 18-20 July, 2-4 August and 22-24 August 1995). Various environmental parameters were measured throughout the study: temperature, discharge, surface irradiance, vertical light attenuation, dissolved nutrients $(\mathrm{N}, \mathrm{P}, \mathrm{Si})$, particulate carbon and nitrogen, chlorophyll $a$ [Chl $a$, by the standard spectrophotometric technique developed by Péchar (1987) or by HPLC analysis (Descy \& Métens, 1996)] and other general measurements, using standard methods detailed elsewhere (see Descy \& Gosselain, 1994).

Phytoplankton was collected from the surface with a 3-1 opaque Van Dorn bottle; 11 was immediately preserved with Lugol's solution. After sedimentation, phytoplankton was examined, under a standard microscope (Leitz Laborlux D:12.5 $\times 40$ magnification) in subsamples mounted in a Bürker cell. Algal units from all samples, save those from the Moselle in 1994, were counted and their dimensions were measured. Data were computed using Hamilton's software (Hamilton, 1990), which records numbers and calculates unit biovolumes from the dimensions entered - except for the samples from the Moselle in 1994. Conversion to carbon (pg C) was then done by means of the Eppley equations or, for the river Moselle in 1994, the Strathmann equations (Smayda, 1978). The level of taxo- nomic ascription for this first examination varied from the species to the genus, according to practical considerations (see Gosselain et al., 1994). Unicellular centric diatoms were counted as one unit or 2-3 categories, according to cell size, in a first step. The relative proportion of centric diatom taxa was determined, in a second step, by counting the frustules mounted in Naphrax at $12.5 \times 100$ magnification, in phase contrast. This step was carried out only for 1994 samples. In this case, individual measurements of the cells were not done so taxon-specific biomass of centric diatoms could not be calculated.

In the annex, mean biomass calculations are presented for the studied period $-\sim$ the growing season - . This was calculated after the data had been completed for missing samples - averaging adjacent values for weeks without data - and then divided by the total number of weeks/fortnight according to the sampling frequency (and months) in the period. When considering diversity and equitability indices, it had to be borne in mind that these calculations were not initially intended. The index values given need to be considered cautiously. Shannon-Wiener diversity and equitability indices were calculated on the total abundances of all species accounting for more than $0.5 \%$ of the biomass during the studied period. As biomass per taxon was not calculated for centric diatoms from the Meuse data, abundances of all centric diatom taxa were taken into account for their calculation. As the 1993-94 data from the Moselle did not cover the whole plankton growing season, we include also data from 1993. As for the 1994 data from the Moselle, units were not measured during counting but a single value of biovolume per taxon was applied.

Primary production was measured in short (between $1 / 2$ and $2 \mathrm{~h}$ ) surface incubations of river water added with $\mathrm{NaH}^{14} \mathrm{CO}_{3}$; subsamples were divided among nine $100 \mathrm{ml}$ glass bottles and exposed to relative irradiances in the range $0-100 \%$ of the sunlight, in a field incubator immersed just beneath the water surface. Sunlight was monitored simultaneously; information was stored by a data logger. The photosynthesis-light relationship was established after measurement of the radioactivity (dpm) of the algae collected on Millipore HA $0.45 \mu \mathrm{m}$ filters; subsequently, daily production was calculated as in Descy et al. (1987).

Subsurface zooplankton was sampled using the same 3-1 Van Dorn bottle and collected on 37 or $63 \mu \mathrm{m}$-mesh Nitex plankton net; a minimum of 151 was collected. Qualitative and quantitative analysis of 
zooplankton samples were performed under a dissecting microscope at $35 \mathrm{X}$ magnification, either on fresh material or on acidifiied Lugol-fixed samples (Leakey et al., 1994), and after concentration by a factor ranging from 250 to 1000 . Rotifers were determined to genus or species level while crustaceans were counted as either cladocerans or copepods, with no further level of identification. Details can be found elsewhere (Viroux, 1997).

\section{Method for grazing experiments}

Grazing measurements were carried out using a 6.5-1 Haney (1971) chamber, the design of which followed Gawler \& Chapuis (1987). Cultures of Dictyosphaerium ehrenbergianum Näg. (which was wholly dominated by Chlorella-like unicells of $4.4 \mu \mathrm{m}$ mean diameter) were used as tracer food. Exponential-phase algae were incubated for at least $24 \mathrm{~h}$ with $250 \mu \mathrm{Ci} \mathrm{NaH}{ }^{14} \mathrm{CO}_{3}$ per $250 \mathrm{ml}$ culture. Flasks containing $15 \mathrm{ml}$ of labelled algae were then prepared so as not to exceed $10 \%$ of the phytoplankton biomass present in the grazing chamber. The carbon/Chl $a$ ratio used for the River Meuse was 37 (Descy \& Gosselain, 1994) and 30 for the River Moselle (based on our own measurements); the carbon content of the cultured algae was assessed by several measurements using a Carlo Erba carbon-nitrogen analyser NA 1500. Incubations in the river lasted between 6 and $11 \mathrm{~min}$ from the closure of the chamber to the end of the sieving of its content through a $37 \mu \mathrm{m}$-mesh (or rarely a $63 \mu \mathrm{m}$-mesh) Nitex screen. This range of time has been chosen as it is shorter than the known gut passage time for most zooplankters (Downing \& Rigler, 1984). The animals were then narcotised in soda water. Before freezing in liquid nitrogen, they were either suspended in a small amount of water (samples for subsequent sorting) or collected on 25-mm Whatman GF/C filters (samples for total community measurements); all samples were stored in $20-\mathrm{ml}$ scintillation vials. A small volume of the water collected from the sieving through the Nitex screen was preserved for determining the radioactivity of the algal suspension. Background corrections were made by running control incubations without any labelled algae: the radioactivity measured on the zooplankton and phytoplankton samples from these controls were subtracted from the counts obtained for the zooplankton and for the algal suspension, respectively. Zooplankton samples collected on $\mathrm{GF} / \mathrm{C}$ filters were treated for the measurement of radioactivity by dissolving animals in $1 \mathrm{ml}$ Lumasolve (Lumac LSC). Com- munity filtering rates (CFR) were calculated according to Haney (1971) and expressed in $\% \mathrm{~d}^{-1}$, i.e. the percentage of the volume filtered per day. Zooplankton ingestion rate could then be calculated by multiplying the daily filtering rate by the algal biomass in the river water (Chl $a$, converted to carbon). In 1994, maximum ingestion rate in the Moselle was calculated, assuming the same impact on the whole algal biomass. In 1995, ingestion rate was corrected for the proportion of edible units, assessed from the phytoplankton counts and size measurements, considering only algal units of greatest axial linear dimension (GALD) $<20 \mu \mathrm{m}$ (Reynolds, 1986). Details of the method will be given elsewhere (Gosselain et al., 1998).

The samples preserved for measuring individual filtering rates (IFR) were sorted and a known number of hand-picked individuals were placed in $6 \mathrm{ml}$ scintillation vials. From individual filtering rates, resulting from these measurements, an assessment of the population filtering rate (SFR, sub-community filtering rate) was made by multiplying the IFR by the corresponding number of individuals in the river water (for details, see Gosselain et al., 1996).

For the purpose of this paper and because IFR were rarely available for all taxa, their contribution was also back-calculated (BCG, back-calculated grazing), by multiplying specific abundances by a species-specific individual filtering rate for each taxon. For rotifers, IFR of Brachionus calyciflorus Pallas and Keratella cochlearis Gosse were used and applied to other taxa, according to size and diet. Global values were applied respectively to nauplii and copepodites. For cladocerans, only Bosmina was excepted from the application of a single estimate. It must be borne in mind that this calculation does not take into account either the algal biomass or influence of the temperature. Nevertheless we assume that it approaches the actual grazing activity when the temperature is greater or equal to $20^{\circ} \mathrm{C}$.

\section{Results}

\section{The Meuse}

In the Meuse, variation in environmental conditions, discharge and temperature during 1994 and 1995 (Figure 2) were similar and quite typical for this river. After a high-flow period, discharges declined in the spring (from mid-April in 1994, early May in 1995) towards the low-flows of summer, which persisted until late September. Temperature followed an opposite pattern. 


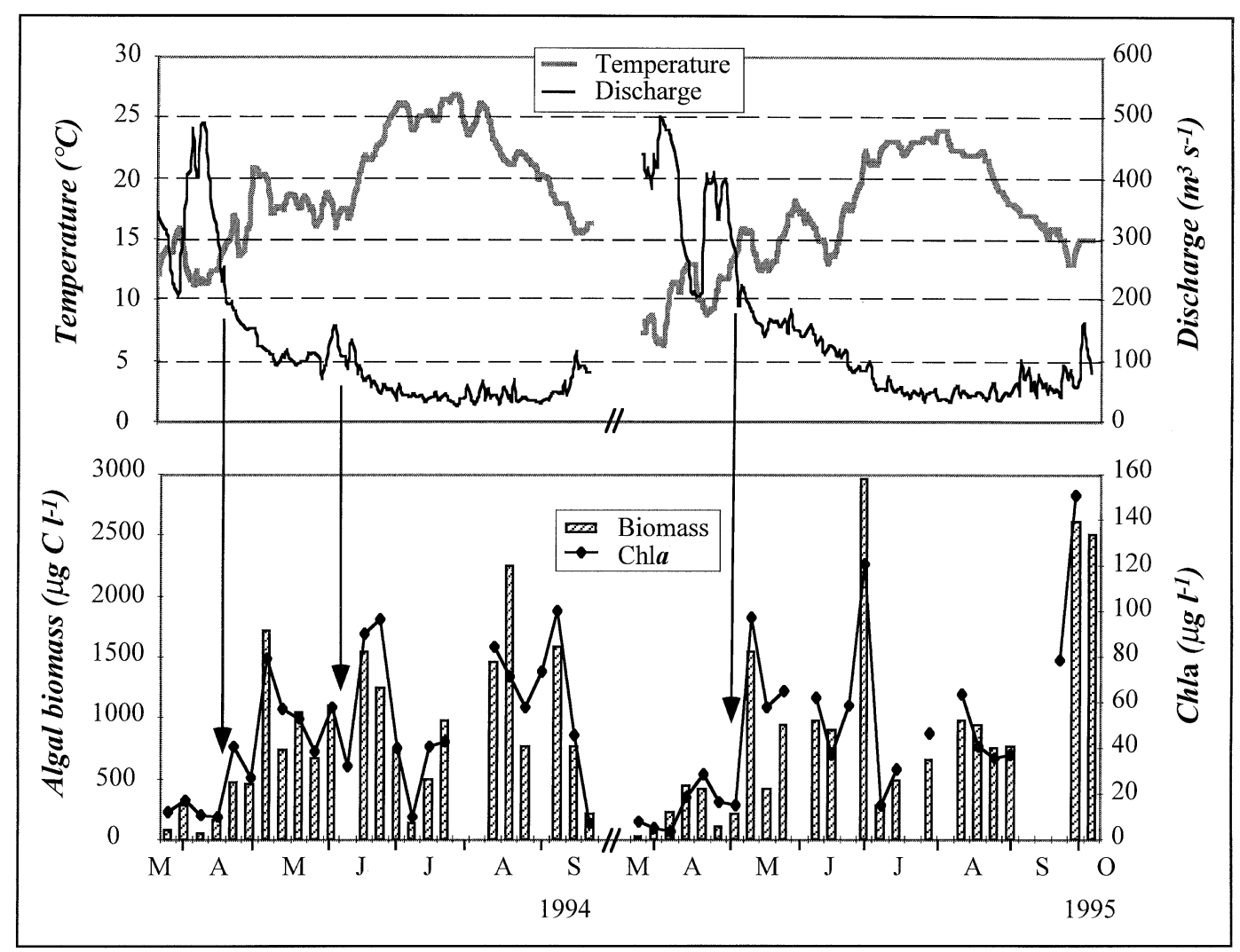

Figure 2. Top - Water discharge $\left(\mathrm{m}^{3} \mathrm{~s}^{-1}\right)$ and temperature $\left({ }^{\circ} \mathrm{C}\right)$ in the River Meuse during the years 1994 and 1995. Data from the CIBE (Compagnie Intercommunale Bruxelloise des Eaux) at Tailfer, close to the study site. Bottom - Variations of phytoplankton at 'La Plante', River Meuse, during the growing season in 1994 and 1995. Bars correspond to biomass $\left(\mu \mathrm{g} \mathrm{C}^{-1}\right.$ ), calculated from cell counting, and the dashed line to the measured $\mathrm{Chl} a\left(\mu \mathrm{g} \mathrm{Chl} a 1^{-1}\right)$. Arrows indicate some discharge events influencing phytoplankton.

The main nutrients $(\mathrm{N}, \mathrm{P}, \mathrm{Si})$ exhibited some variations but remained always well above concentrations limiting algal growth (see annex).

In both years, a first algal bloom followed the spring decrease in water discharge. Algal biomass then declined, perhaps because of lower temperature. A second bloom built up, with a maximum at the end of June (reaching the maximum $\mathrm{Chl} a$ concentration of the year in 1995 , close to $160 \mu \mathrm{g} \mathrm{l}^{-1}$ ), at a time when temperature and discharge were optimal for plankton growth. At the beginning of July, in both years, a sharp ten-fold decrease in phytoplankton was then observed, followed by a quick recovery. Maximum Chl $a$ concentration in 1994 was observed during the late summer period (around $100 \mu \mathrm{g} \mathrm{l}^{-1}$ ). In 1995, the high biomass recorded at the end of September was probably related to changes in flow rate and retention times resulting from river regulation operations.
In both years, centric diatoms were dominant throughout the growing season (Figure 3). Green algae began to develop in May, probably responding to higher temperatures and improved light income. Algae of other phylogenetic groups appeared at this time but remained at relatively low levels. In 1994, green algae played a more important role in the second bloom (end of June) than in 1995, but Peridinium sp. reached a high biomass. During this first part of the algal development, unit sizes were in the range 5-15 $\mu \mathrm{m}$ GALD (yet with a significant biomass in the 20-25 $\mu \mathrm{m}$ GALD range in 1995). As far as the zooplankton is concerned, a spring 'bloom' of rotifers developed in May (253 ind. $1^{-1}$ on 23 May 1994 and 677 ind. $1^{-1}$ on 8 June 1995; see Figure 3); Euchlanis sp., along with B. calyciflorus in 1994 and with $K$. cochlearis and Synchaetidae in 1995, were the dominant taxa of this episode (Figure 4; bottom). In 1994, this phase was followed by an intense pulse of $D$. polymorpha veligers. In 1995, on 


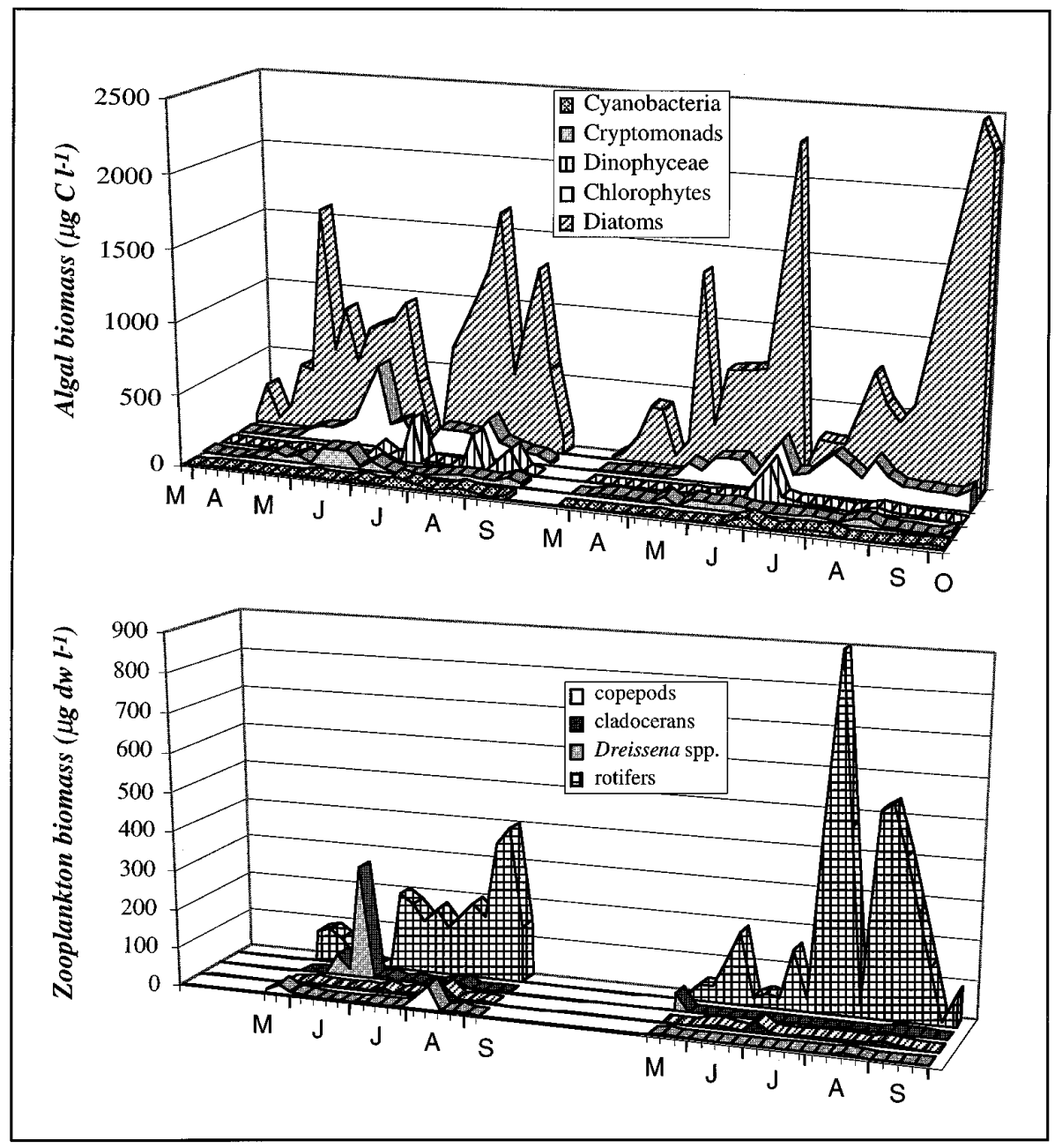

Figure 3. Variations of the main algal groups expressed in biomass $\left(\mu \mathrm{g} \mathrm{C}^{-1} ;\right.$ top $)$ and variations of zooplankton expressed in biomass $(\mu \mathrm{g} \mathrm{dw}$ $1^{-1} ;$ bottom $)$ at 'La Plante', River Meuse, during the growing season in 1994 and 1995.

the other hand, Dreissena veligers were observed only once, in May, with 91 ind. $1^{-1}$. Nevertheless, a peak may have occurred before sampling started.

At the beginning of July, a sharp, ten-fold algal decrease occurred: populations of all algal groups diminished, particularly of species with GALD in the range 5-15 $\mu \mathrm{m}$ (and, notably, those in the 15-20 $\mu \mathrm{m}$ GALD range in 1995). At this time, rotifers increased in numbers and biomass, more especially so in 1994.

A slow recovery in algal numbers followed and filamentous centrics (Aulacoseira spp. with a few Skeletonema potamos) became more prominent and were the dominant centrics for about 3 weeks at the end of August in 1994, and in one sample in 1995 (August 25).
In this summer period, a certain broadening of the distribution of algal size was observed in both years. The effect was more noticeable in 1994 than in 1995: units larger than $25 \mu \mathrm{m}$ GALD were never significant in 1995 but the 130-180 $\mu$ m GALD was well represented in the second half of August 1994.

Zooplankton biomass during mid-summer remained relatively high in both years (reaching $200 \mu \mathrm{g} \mathrm{dw}^{-1}$ around 1500 ind. $1^{-1}$ - in 1994, and close to $500 \mu \mathrm{g} \mathrm{dw}$ $1^{-1}-$ around 2000 ind. $1^{-1}-$ in 1995). The dominant species were nevertheless quite different from one year to the other. In 1994, B. calyciflorus and B. angularis Gosse shared dominance, while in 1995, K. cochlearis dominated over all other rotifer species. Significant 


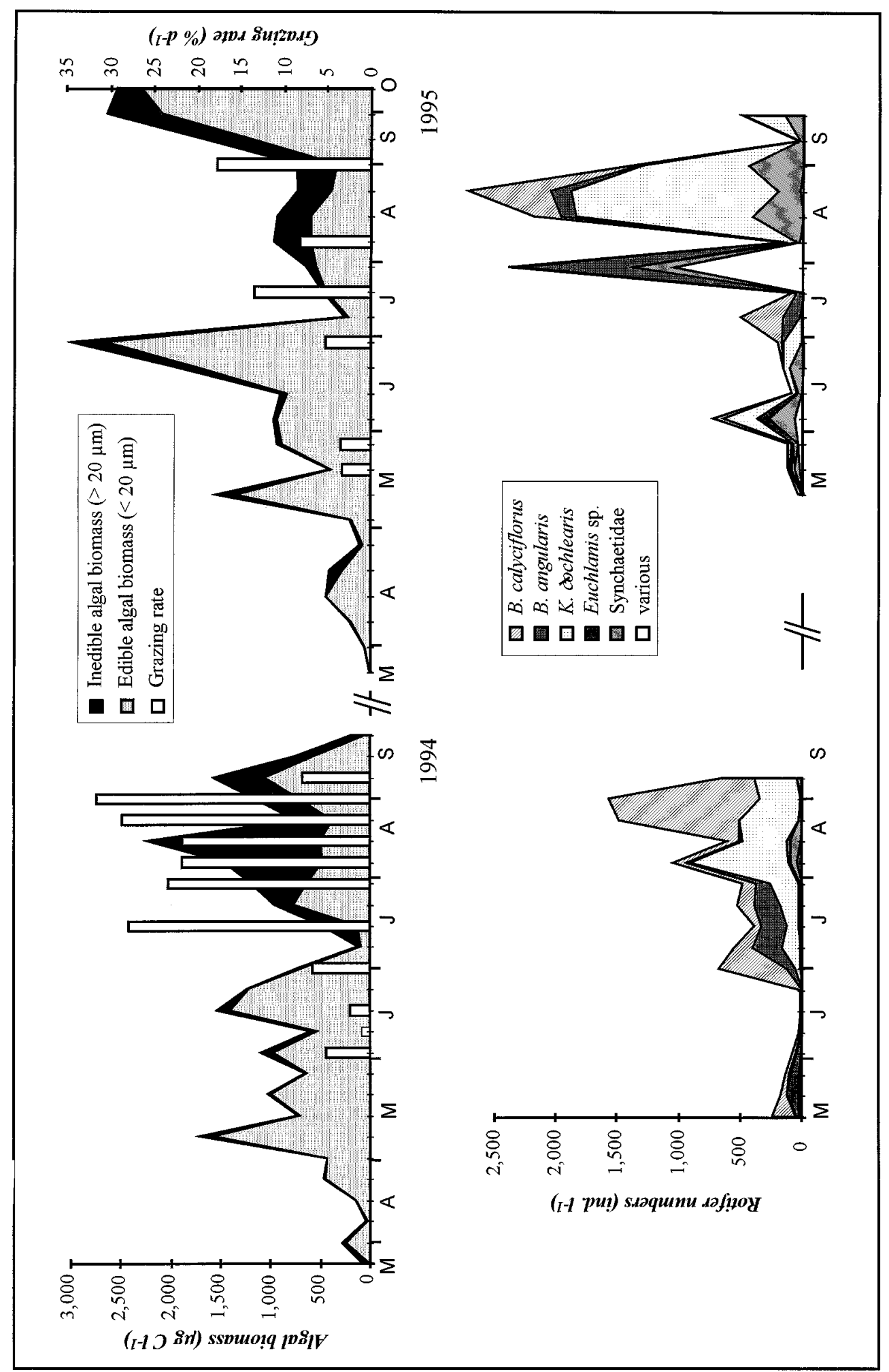

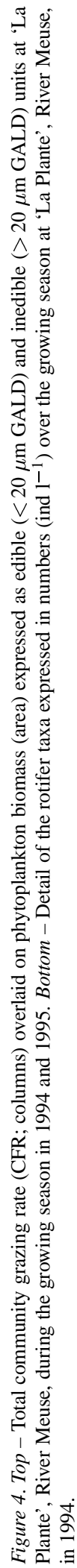


numbers of small cladocerans appeared in August 1994 (6.5 ind. $1^{-1}$ or $32.3 \mu \mathrm{g} \mathrm{dw} \mathrm{^{-1 }}$ ), with Bosmina spp. making up about $15 \%$ of them. They reappeared in late June 1995 (12.2 ind. $\mathrm{l}^{-1}$ or $27.2 \mu \mathrm{g} \mathrm{dw} \mathrm{l}^{-1}$ ), when Bosmina spp. represented $98 \%$ of them. Copepodites reached maximum densities in August (6.7 ind. $1^{-1}$ in 1994 and 2.1 ind. $1^{-1}$ in 1995).

In Figure 4, measured grazing rates are superimposed on the phytoplankton biomass changes within two broad size categories: less than $20 \mu \mathrm{m}$ GALD, considered as edible by the rotifer-dominated zooplankton, and greater than $20 \mu \mathrm{m}$ GALD, assumed to be inedible; the lower diagrams show the parallel dynamics of the rotifers. Grazing activity in 1994, expressed as a daily rate, ranged between 1 and $32 \%$ of the total volume, and remained over $20 \% \mathrm{~d}^{-1}$ throughout July and August. The five 1995 measurements done in 1995 yielded daily rates of between 3.4 and $17.9 \% \mathrm{~d}^{-1}$. These diagrams strongly suggest, for both years of measurement, a link between a relatively well diversified rotifer population, relatively high grazing rates and a change in size structure of the phytoplankton community, i.e. in a wide range of sizes contrasting with the narrow spring GALD range. In summer 1994, the clear shift to larger algae was seemingly influenced by the grazing pressure applied to the smaller algae. Had the edible biomass in summer 1995 been in the same range as in 1994, the biomass of larger algae would perhaps have remained as low as in 1994.

Supposing the zooplankton to have been feeding only on the edible algal fraction $(<20 \mu \mathrm{m}$ GALD), grazing losses in 1994 comprised between 69 and $301 \mu \mathrm{g} \mathrm{C}^{-1} \mathrm{~d}^{-1}$ (which, on an areal basis, is equivalent to $\left.274-1188 \mathrm{mg} \mathrm{C} \mathrm{m}^{-2} \mathrm{~d}^{-1}\right)$ and, in 1995, between 70 and $211 \mu \mathrm{g} \mathrm{C}^{-1} \mathrm{~d}^{-1}$ (276-834 $\left.\mathrm{mg} \mathrm{C} \mathrm{m}^{-2} \mathrm{~d}^{-1}\right)$, with the highest values corresponding to the algal bloom on June 29.

Rotifer sub-community filtering rates (SFR), calculated for 1994, showed a rotifer contribution to total grazing (CFR) ranging between 40 and $134 \%$ (see Gosselain et al., 1996). Back-calculated filtering rates $(\mathrm{BCG})$ indicate that rotifers represent the major contributor to total grazing. Most of the time, the rotifer BCG was ten times higher than that of the crustacean contribution; significant consumption by micro-crustaceans, principally by Bosmina, was found only once (12.5\% of total BCG on June 29,1995$)$.

\section{The Moselle}

The phytoplankton of the Moselle was similar in composition to that of the Meuse: in the two years, centric diatoms largely dominated at all stations, except for occasional, local developments of other types of algae, including Dinophyceae in July 1994 (Figure 5), or green algae and Cryptophyceae in 1995 (not shown). A first spring bloom occurred in April and a second bloom reached its maximum at the end of June; it was composed of various small centric diatoms. It is worth noticing that this bloom declined downstream. The zooplankton community (Figures $5 \& 6$ ), made of rotifers and, at times, Dreissena larvae, bloomed at the same periods as phytoplankton. In June 1994, total zooplankton numbers rose to $4400-6500$ ind. $1^{-1}$ (1300-1600 $\mu \mathrm{g} \mathrm{dw}^{-1}$ ), depending on the station. In 1995 , spring peaks were less marked, reaching only 750 ind. $1^{-1}\left(180 \mu \mathrm{g} \mathrm{dw} 1^{-1}\right)$, except at Hauconcourt (1300 ind. $1^{-1}$ or $250 \mu \mathrm{g} \mathrm{dw} 1^{-1}$ for the second spring bloom). Dominant taxa were B. calyciflorus, $B$. angularis and K. cochlearis in 1994 and B. calyciflorus, Synchaeta sp. and K. cochlearis in 1995.

A summer algal biomass decline, affecting all groups in a similar way, was observed from July downstream of the French border and somewhat later in the upstream sector. At this time, rotifer numbers were already low and the low algal biomass level was observed during the entire second part of summer. Detailed analyses of unit sizes, carried out in 1995 for the date of experiments, indicated a progressive shift from small (6-19 $\mu \mathrm{m}$ GALD) to large units $(>20 \mu \mathrm{m}$ GALD) among unicellular centrics. A longitudinal decrease of filamentous diatoms is also to be noticed. From early August on, zooplankton decreased, as did the phytoplankton, and remained at low levels (Figure 6). During this period, crustaceans were dominant on a biomass basis and also, most of the time, in terms of abundance. In 1995, they persisted for some weeks. Dreissena larvae dominated the zooplankton over the whole summer.

Grazing and primary production were measured in early August in 1994 (Figure 5), at a time when zooplankton numbers were between 100 and 350 ind. $1^{-1}$ (which was $110-313 \mu \mathrm{g} \mathrm{dw} 1^{-1}$ without taking into account Dreissena veligers). Grazing rates were approximated to be between 8 and $15 \% \mathrm{~d}^{-1}$. In 1994 , grazing was expressed as maximum ingestion over the water column and compared to algal net production. It is striking that consumption by grazers, in the range $30.2-149.0 \mu \mathrm{g} \mathrm{C}^{-1} \mathrm{~d}^{-1}$ (which is $121.0-521.6 \mathrm{mg}$ 


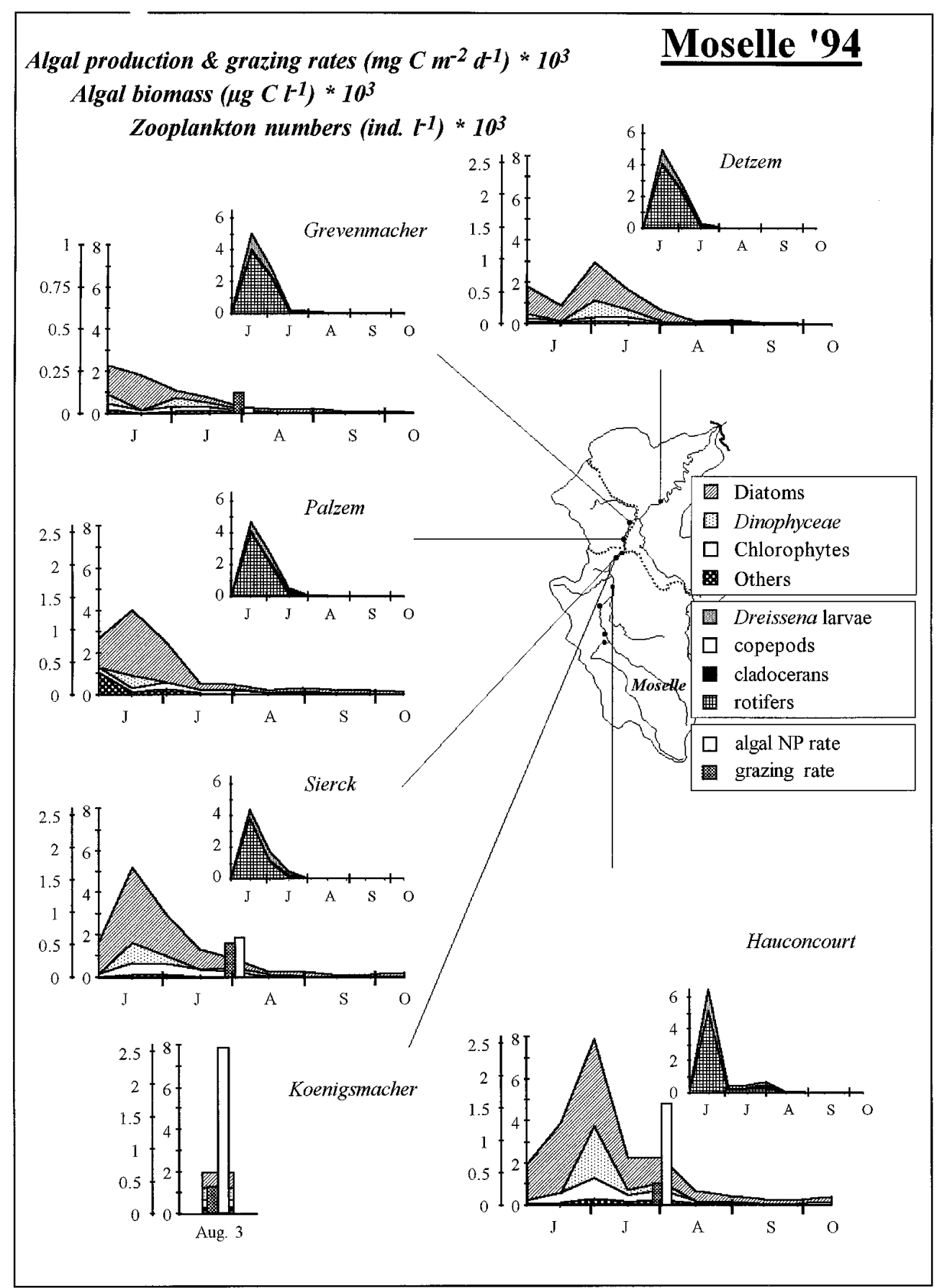

Figure 5. Variations of the main algal groups, expressed as biomass ( $\mu \mathrm{g} \mathrm{Cl}^{-1}$; inner axes), and variations of zooplankton, expressed in numbers (ind $1^{-1}$ ) at different stations in the River Moselle from June 1994 and till the end of the growing season. Phytoplankton net production and losses by grazing are overlaid as bars and are expressed as carbon areal values ( $\mathrm{mg} \mathrm{C} \mathrm{m}^{-2} \mathrm{~d}^{-1}$; outer axes). 


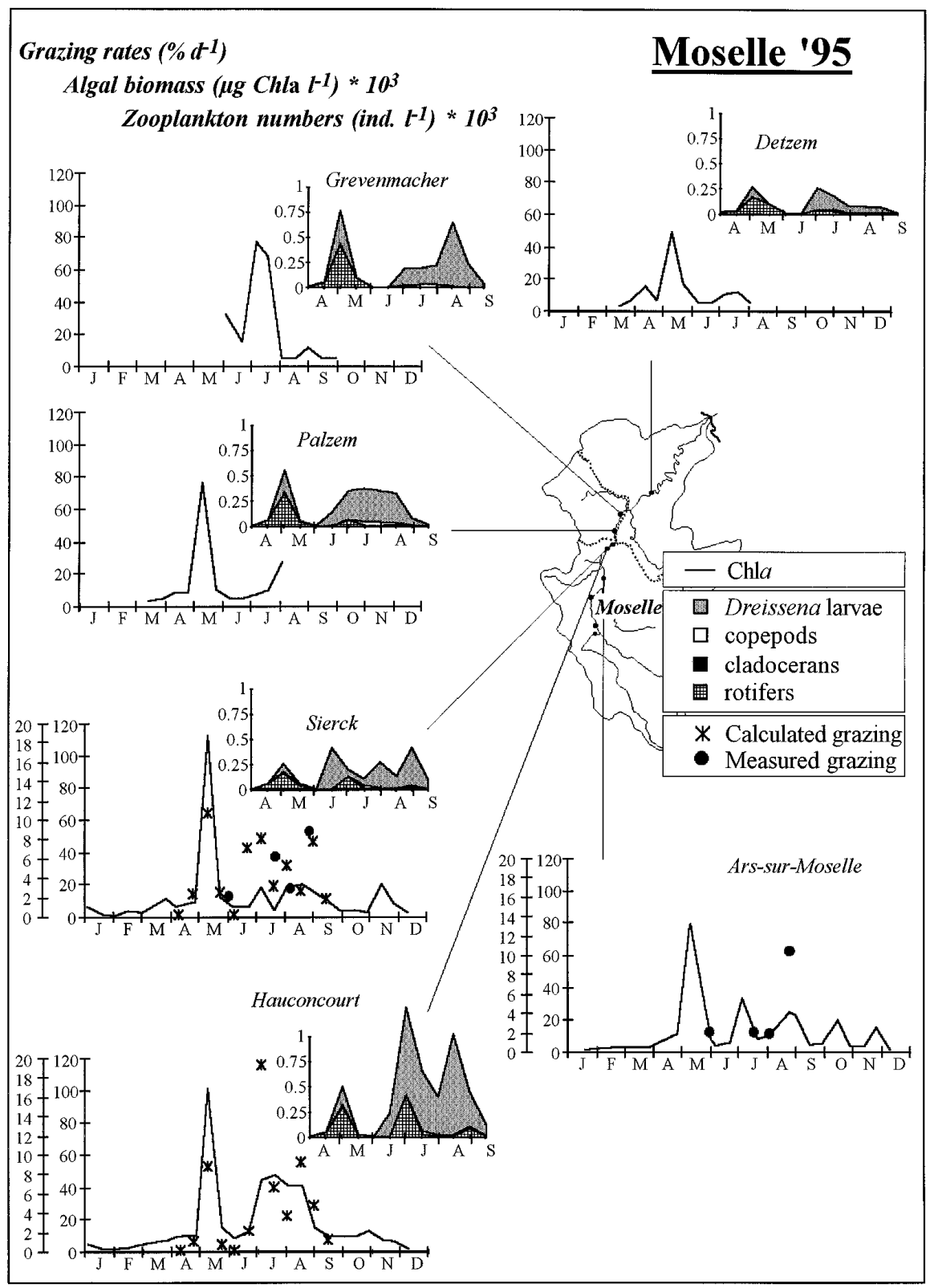

Figure 6. Variations of Chl $a$ ( $\mu \mathrm{g} \mathrm{Chl} a 1^{-1}$; data from the IRH, Nancy, France, from the DEAL, Luxembourg and from the LfW, Germany), and variations of zooplankton, expressed in numbers (ind $1^{-1}$ ) at the different stations in the River Moselle during the growing season in 1995. Measured grazing (CFR) and back-calculated grazing (BCG) overlaid on Chl $a$ curves for 3 of the sampling stations.

$\mathrm{C} \mathrm{m}^{-2} \mathrm{~d}^{-1}$ ), may exceed phytoplankton production. Indeed, algal production may be very low in the deepest sectors, as in Grevenmacher. In 1995, as could be expected from the low zooplankton numbers, grazing rates were also relatively low, between 1 and $11 \%$ $\mathrm{d}^{-1}$ (Figure 6). Considering the edible phytoplankton fraction, losses through grazing $(2.9-245.5 \mathrm{mg}$
$\mathrm{C} \mathrm{m}^{-2} \mathrm{~d}^{-1}$; Figure 7) represented up to $22 \%$ of algal net production $\left(<0-1690 \mathrm{mg} \mathrm{C} \mathrm{m}^{-2} \mathrm{~d}^{-1}\right.$; Figure 7). The back-calculated filtering rates (BCG; Figure 6) for 1995 show, by contrast with the River Meuse, that the crustacean contribution to community grazing may approach or exceed that of rotifers. They are in agreement with total community filtering rates. 


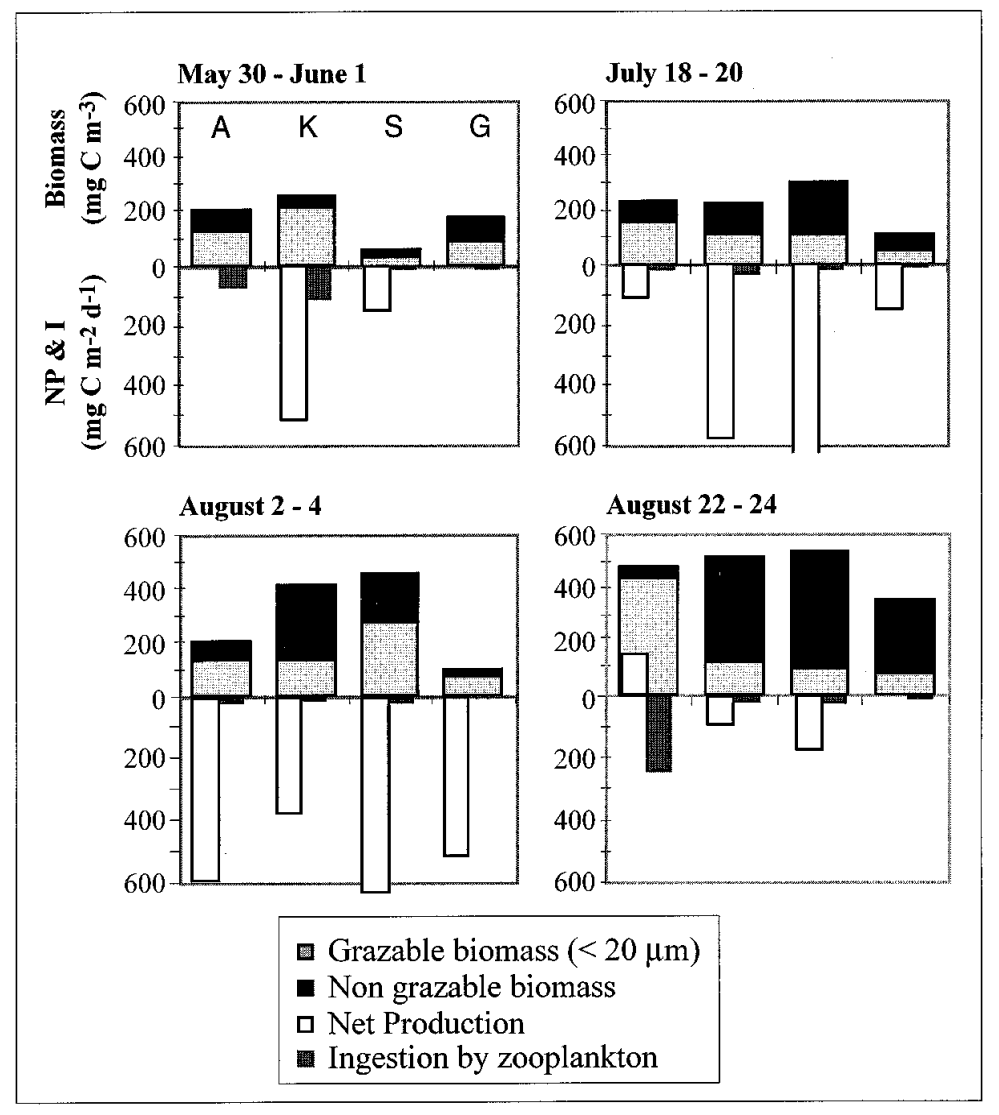

Figure 7. Phytoplankton biomass (top bars) expressed as edible $(<20 \mu \mathrm{m}$ GALD) and inedible $(>20 \mu \mathrm{m}$ GALD) biomass at the different stations and for the four sampling series in the River Moselle in 1995. Phytoplankton net production (NP) and losses by grazing (I) are given in parallel (bottom part of the graphs) and expressed as carbon areal values $\left(\mathrm{mg} \mathrm{C} \mathrm{m}^{-2} \mathrm{~d}^{-1}\right.$ ). The four stations are: $\mathrm{A}=\mathrm{Ars}-\mathrm{sur}-\mathrm{Moselle}$; $\mathrm{K}=$ Koenigsmacher; $\mathrm{S}=$ Sierck; $\mathrm{G}=$ Grevenmacher. Note that algal production was not measured at Ars on the first date and at Grevenmacher on the first and fourth dates.

\section{Discussion and conclusion}

Although different sampling strategies were applied to the two rivers, the datasets permit interesting comparisons of the plankton dynamics and of the processes involved. Both rivers exhibit a similar phytoplankton, which responded to discharge, light and temperature in predictable ways (see e.g. Descy et al., 1987). Notable differences between them surround the events in summer, after the onset of zooplankton development in 1994 and 1995: the phytoplankton decrease was of short duration in the Meuse, while a low algal biomass persisted through the whole summer in the Moselle. In both rivers, the proportion of large units of phytoplankton increased in the mid-summer algal assemblage.

The sequence of zooplankton development was similar in both rivers and conforms to what has been observed in other studies: the typical riverine community is composed of various rotifers, able to develop quickly as favourable physical conditions occur, and which seem to need the large amounts of edible algae supplied by the spring bloom if they are to achieve maximal development (Marneffe et al., 1996; de Ruyter van Steveninck et al., 1992). The difference between the two rivers lies in the low summer biomass of zooplankton in the Moselle, at a time when, in the Meuse, zooplankton achieve the largest numbers and biomass. It is also worth noticing the greater contribution by micro-crustaceans in the Moselle. The rivers also differ in the abundance of Dreissena veligers present, which reached much higher numbers in the Moselle (this study and Viroux, 1997).

When it comes to zooplankton grazing, the results from the Meuse clearly point to a significant influence 
on the phytoplankton community. The key observations are the following:

(i) the buildup of the rotifer community in spring corresponds to the decline of the algal spring bloom; this does not exclude other losses, for instance, through enhanced sedimentation or mortality by parasitism (Gosselain et al., 1994);

(ii) the dense rotifer assemblage was able to graze the algae at rates exceeding $20 \% \mathrm{~d}^{-1}$ throughout the summer; the measured grazing rates reached $32 \%$ $\mathrm{d}^{-1}$, which can be compared to the values calculated for the River Rhine by de Ruyter van Steveninck et al. (1992) from the rotifer populations developed in the river. Values resulting from simulations with mathematical models (Gosselain et al., 1994; Garnier et al., 1995) are in the same range;

(iii) a distinct change in the size structure of the algal community occurred in summer; it may be due to highly size-selective grazing pressure by small zooplankton; their grazing may at times exceed primary production rates and thus control the biomass of small algal units edible by rotifers (Gosselain et al., 1998).

The grazing rates measured in either river clearly reflect rotifer abundance and this observation validates calculations of grazing losses based on zooplankton numbers. However, there seems to be a significant influence of community composition: for instance, rotifer assemblages dominated by Brachionus spp. typically graze at higher rates than those dominated by smaller taxa, as Keratella spp.. Community grazing rates may also increase when crustaceans, even small taxa, represent a large share of the zooplankton biomass, as in the Moselle in summer.

However, the summer decline in the Moselle is still far from being fully explained. In spite of favourable physical conditions, phytoplankton and zooplankton biomass remained at low levels from mid-summer on and measurements of zooplankton grazing were in a lower range than in the Meuse. Nevertheless, it is to be emphazised that all in situ grazing assays were performed in summer, after the phytoplankton and zooplankton blooms. When considering the spring rotifer numbers, it appears that the decrease of the spring algal bloom was likely due to grazing by this abundant zooplankton. For instance, back-calculated grazing (BCG) for June 22, 1994 gives values ranging between 93 and $165 \% \mathrm{~d}^{-1}$ depending on to the station but reached only $13 \% \mathrm{~d}^{-1}$ at the plankton spring bloom in 1995.

Further, more crustaceans have been recorded in summer in the Moselle than in the Meuse. The role of crustaceans is still unclear, owing to the probable patchiness of these organisms. Their grazing activity may not have been correctly evaluated, as indicated by the number of animals retrieved from the Haney chamber, compared to the abundance estimates from larger sampling volumes of river water.

Whatever the uncertainties remaining about zooplankton grazing in the River Moselle, it appears that the long-lasting summer decline of the plankton of this river requires another explanation. Various data collected during the period of study (Bachmann et al., 1997) indicate that high densities of benthic filterfeeders exist in the River Moselle. Although the mean densities are difficult to evaluate due to extreme patchiness of the bottom substrata, areal densities (ind. $\mathrm{m}^{-2}$ ) between 700 and $7000 \mathrm{D}$. polymorpha adults, 17 to 8800 Corbicula sp. and 12 to 97500 Corophium curvispinum have been reported in the studied river section. As mentioned in the introduction, several studies point to a very dense incidence of benthic filter-feeders in rivers where they can develop dense populations. In the Moselle, predation by these animals, which are able to ingest particles over a wide size spectrum, might explain the summer depression of both phytoplankton and zooplankton.

We conclude from this comparison between two eutrophic lowland rivers that significant biotic interactions may develop within the potamoplankton. In contrast to other studies dealing with the interaction between zoo- and phytoplankton in rivers (de Ruyter van Steveninck, 1992; Basu \& Pick, 1997), we based our approach on direct measurements of zooplankton grazing. In this way, daily grazing rates are directly comparable with phytoplankton production rates, as well as to other loss rates (sedimentation, mortality,...). Our results point to a significant zooplankton control over phytoplankton, provided that the zooplankton community be well-developed and diversified. In the Meuse and Moselle rivers, zooplankton biomass can reach $500 \mu \mathrm{g} \mathrm{dw} 1^{-1}$ (Marneffe et al., 1996) and $1600 \mu \mathrm{g} \mathrm{dw} \mathrm{l}^{-1}$ (this study), respectively. Consequently, potential grazing rates may be even higher than those measured in our study. One of the most important features of the phytoplankon-zooplankton interaction in rivers is its strong dependency upon flow rate, which must be slow enough for a long period of time (several weeks) to allow zooplankton development along the course of the river. The zooplankton assemblage, dominated by r-strategists, is inherently unstable and may fluctuate, so that the grazing pressure on planktonic algae is highly variable. For instance, there is a 
large within-year and year-to-year variability of zooplankton in the Meuse and Moselle rivers related to meteorological and hydrological fluctuations. However, another cause of zooplankton variability may be predation, for instance by benthic filter-feeders, as it seems to be the case in the River Moselle.

\section{References}

Admiraal, W., L. Breebart, G. M. J. Tubbing, B. van Zanten, E. D. de Ruyter van Steveninck \& R. Bijkerk, 1994. Seasonal variation in composition and production of planktonic communities in the lower River Rhine. Freshwat. Biol. 32: 519-531.

Aldridge, C. W., B. S. Payne \& A. C. Miller, 1995. Oxygen consumption, nitrogenous excretion, and filtration rates of Dreissena polymorpha at acclimation temperatures between 20 and $32{ }^{\circ} \mathrm{C}$. Can. J. Fish. aquat. Sci. 52: 1761-1767.

Bachmann, V., E. Cegielka, P. Wagner, P. Usseglio-Poltera \& J. C. Moreteau, 1997. Installation de l'amphipode Corophium curvispinum et de la palourde asiatique Corbicula sp. dans le cours français de la Moselle - Establishment of the Amphipod Corophium curvispinum and the Asiatic Clam Corbicula sp. in the French part of the Mosel river. Hydroécol. Appl. 7: 185-191.

Basu, B. K. \& F. R. Pick, 1997. Phytoplankton and zooplankton development in a lowland, temperate river. J. Plankton Res. 19: 237-253.

Böhme, M., 1994. Release and consumption of oxygen by a phytoplankton dominated community of a eutrophic lowland river. Verh. int. Ver. Limnol. 25: 1585-1589.

de Ruyter van Steveninck, E. D., W. Admiraal, L. Breebaart, G. M. J. Tubbing \& B. van Zanten, 1992. Plankton in the River Rhine: structural and functional changes observed during downstream transport. J. Plankton Res. 14: 1351-1368.

Descy, J.-P., 1993. Ecology of the phytoplankton of the River Moselle: effects of disturbances on community structure and diversity. Hydrobiologia 249: 111-116.

Descy, J.-P. \& C. Willems, 1991. Contribution à la connaissance du phytoplancton de la Moselle (France). Cryptogamie, Algol. 12: 87-100.

Descy, J.-P. \& V. Gosselain, 1994. Ecological importance and dynamics of phytoplankton in a large lowland river (River Meuse, Belgium). Hydrobiologia 289: 139-155.

Descy, J.-P. \& A. Métens, 1996. Biomass-pigment relationships in potamoplankton. J. Plankton Res. 18: 1557-1566.

Descy, J.-P., P. Servais, J. S. Smith, G. Billen \& E. Everbecq, 1987. Phytoplankton biomass and production in the River Meuse (Belgium). Wat. Res. 21: 1557-1566.

Downing, J. A. \& F. H. Rigler, 1984. A manual on methods for the assessment of secondary productivity in fresh waters. IBP Handbook 17; Blackwell scientific publications, Oxford.

Effler, S. W., C. M. Brooks, K. Whitehead, B. Wagner, S. M. Derr, M. Perkins, C. A. Siegfried, L. Walrath \& R. P. Canale, 1996. Impact of zebra mussel invasion on river water-quality. Wat. Env. Res. 68: 205-214.
Garnier, J., G. Billen \& M. Coste, 1995. Seasonal succession of diatoms and chlorophyceae in the drainage network of the River Seine: Observations and modelling. Limnol. Oceanogr. 40: 750765.

Gawler, M. \& R. Chapuis, 1987. An improved version of the Haney grazing chamber. Freshwat. Biol. 18: 1-4.

Gosselain, V., J.-P. Descy \& E. Everbecq, 1994. The phytoplankton community of the River Meuse, Belgium: seasonal dynamics (year 1992) and the possible incidence of zooplankton grazing. Hydrobiologia 289: 179-191.

Gosselain, V., L. Viroux, \& J.-P. Descy, 1998. Can a community of small-bodied grazers control phytoplankton in rivers? Freshwat. Biol. 39: 9-24.

Gosselain, V., C. Joaquim-Justo, L. Viroux, M. Mena, A. Métens, J.-P. Descy \& J.-P. Thomé, 1996. Laboratory and in situ grazing rates of freshwater rotifers and their contribution to community grazing rates. Arch. Hydrobiol. Suppl. 113: 353-361.

Hamilton, P., 1990. The revised edition of a computerized plankton counter for plankton, periphyton and sediment diatom analyses. Hydrobiologia 194: 23-30.

Haney, J. F., 1971. An in situ method for the measurement of zooplankton grazing rates. Limnol. Oceanogr. 16: 971-977.

Köhler, J., 1995. Growth, production and losses of phytoplankton in the lowland River Spree: carbon balance. Freshwat. Biol. 34: $501-512$.

MacIssac, H. J., C. J. Lonnee \& J. H. Leach, 1995. Suppression of microzooplankton by zebra mussels: importance of mussel size. Freshwat. Biol. 34: 379-387.

MacIsaac, H. J., W. G. Sprules, O. E. Johannsson \& J. H. Leach, 1992. Filtering impacts of larval and sessile zebra mussels (Dreissena polymorpha) in western Lake Erie. Oecologia 92: 30-39.

Marneffe, Y., J.-P. Descy \& J.-P. Thomé, 1996. The zooplankton of the lower River Meuse, Belgium: seasonal changes and impact of industrial and municipal discharges. Hydrobiologia 317: 1-16.

Reynolds, C. S., 1986. Experimental manipulations of the phytoplankton periodicity in large limnetic enclosures in Blelham Tarn, English Lake District. Hydrobiologia 138: 43-64.

Reynolds, C. S. \& J.-P. Descy, 1996. The production, biomass and structure of phytoplankton in large rivers. Arch. Hydrobiol. Suppl. 113: $161-187$.

RIWA, 1996a. Rapport annuel 1994 - Tome B: la Meuse, RIWA, Amsterdam, septembre 1996, 144 pp.

RIWA, 1996b. Rapport annuel 1995 - Tome B: la Meuse, RIWA, Amsterdam, février 1996, $128 \mathrm{pp}$.

Smayda, T. J., 1978. From phytoplankters to biomass. In Sournia, A. (ed), Phytoplankton Manual. UNESCO, Paris: 273-279.

Sprung, M., 1995. Physiological energetics of the zebra mussel Dreissena polymorpha in lakes. II. Food uptake and gross growth efficiency. Hydrobiologia 304: 133-146.

Vannote, R. L., G. W. Minshall, K. W. Cummins, J. R. Sedell \& C. E. Cushing, 1980. The river continuum concept. Can. J. Fish. aquat. Sci. 37: 130-137.

Viroux, L., 1997. Zooplankton development in two large lowland rivers, the Moselle (France) and the Meuse (Belgium), in 1993. J. Plankton Res. 19: 1743-1762. 


\section{Physical \& chemical data}

\begin{tabular}{|c|c|}
\hline Site & "La Plante" \\
\hline Location latitude & $50^{\circ} 26^{\prime} 45^{\prime \prime} \mathrm{N}$ \\
\hline longitude & $4^{\circ} 50^{\prime} 40^{\prime \prime} \mathrm{E}$ \\
\hline Mean depth & $3.95 \mathrm{~m}$ \\
\hline Mean width & $100 \mathrm{~m}$ \\
\hline Residence time & $\sim 4$ days for a $30 \mathrm{~km}$ sector in summer conditions \\
\hline Mixing frequency & always mixed and homogenous for phytoplankton \\
\hline Ice cover & none \\
\hline
\end{tabular}

\begin{tabular}{|c|c|c|c|c|c|}
\hline & & $\min$. & Max. & Mean & $\mathrm{n}$ \\
\hline Total P & $\mu \mathrm{g} \mathrm{P} \mathrm{l^{-1 }}$ & 62.7 & 187 & 132.8 & 16 \\
\hline Total N & $\mathrm{mg} \mathrm{N}^{-1}$ & 2.3 & 16.3 & 4.3 & $(12)^{a}$ \\
\hline SRP & $\mu \mathrm{g} \mathrm{P}^{-1}$ & 5 & 210 & 71 & $50^{\mathrm{a}}$ \\
\hline DIN & $\mathrm{mg} \mathrm{N} \mathrm{^{-1 }}$ & 1.4 & 3.6 & 2.4 & 15 \\
\hline $\mathrm{pH}$ & & 7.4 & 8.8 & 8.2 & 24 \\
\hline Alkalinity & meq $1^{-1}$ & 2.2 & 4.0 & 3.3 & 21 \\
\hline Suspended matter & $\mathrm{mg} \mathrm{l}^{-1}$ & 2.6 & 106 & 17.5 & $52^{\mathrm{a}}$ \\
\hline Extinction coefficient & $\mathrm{m}^{-1}$ & 1.2 & 4.7 & 2.4 & 25 \\
\hline
\end{tabular}

\begin{tabular}{|c|c|c|c|c|c|}
\hline & & $\min$. & Max. & Mean & $\mathbf{n}$ \\
\hline Total P & $\mu g \mathrm{P}^{-1}$ & 59 & 296 & 169.8 & 9 \\
\hline Total N & $\mathrm{mg} \mathrm{N}^{-1}$ & 3.3 & 3.8 & 3.6 & $(9)^{a}$ \\
\hline SRP & $\mu \mathrm{g} \mathrm{P} \mathrm{l^{-1 }}$ & 2 & 297 & 55 & $52^{a}$ \\
\hline DIN & $\mathrm{mg} \mathrm{N} \mathrm{I}^{-1}$ & 1.7 & 4.1 & 2.6 & 27 \\
\hline $\mathrm{pH}$ & & 7.3 & 8.8 & 8.1 & 16 \\
\hline Alkalinity & meq $\mathrm{l}^{-1}$ & 1.4 & 3.8 & 2.9 & $52^{\mathrm{a}}$ \\
\hline Suspended matter & $\mathrm{mg} \mathrm{l}^{-1}$ & 3.0 & 204 & 26.3 & $50^{\mathrm{a}}$ \\
\hline Extinction coefficient & $\mathrm{m}^{-1}$ & 1.7 & 4.3 & 2.8 & 15 \\
\hline
\end{tabular}

a values from RIWA (1996a, 1996b) at Tailfer, close to the sampling station. Numbers of samples (n) are in brackets when the values are calculated from monthly means. 
Phytoplankton data (see material \& methods chapter for more explanations)

year

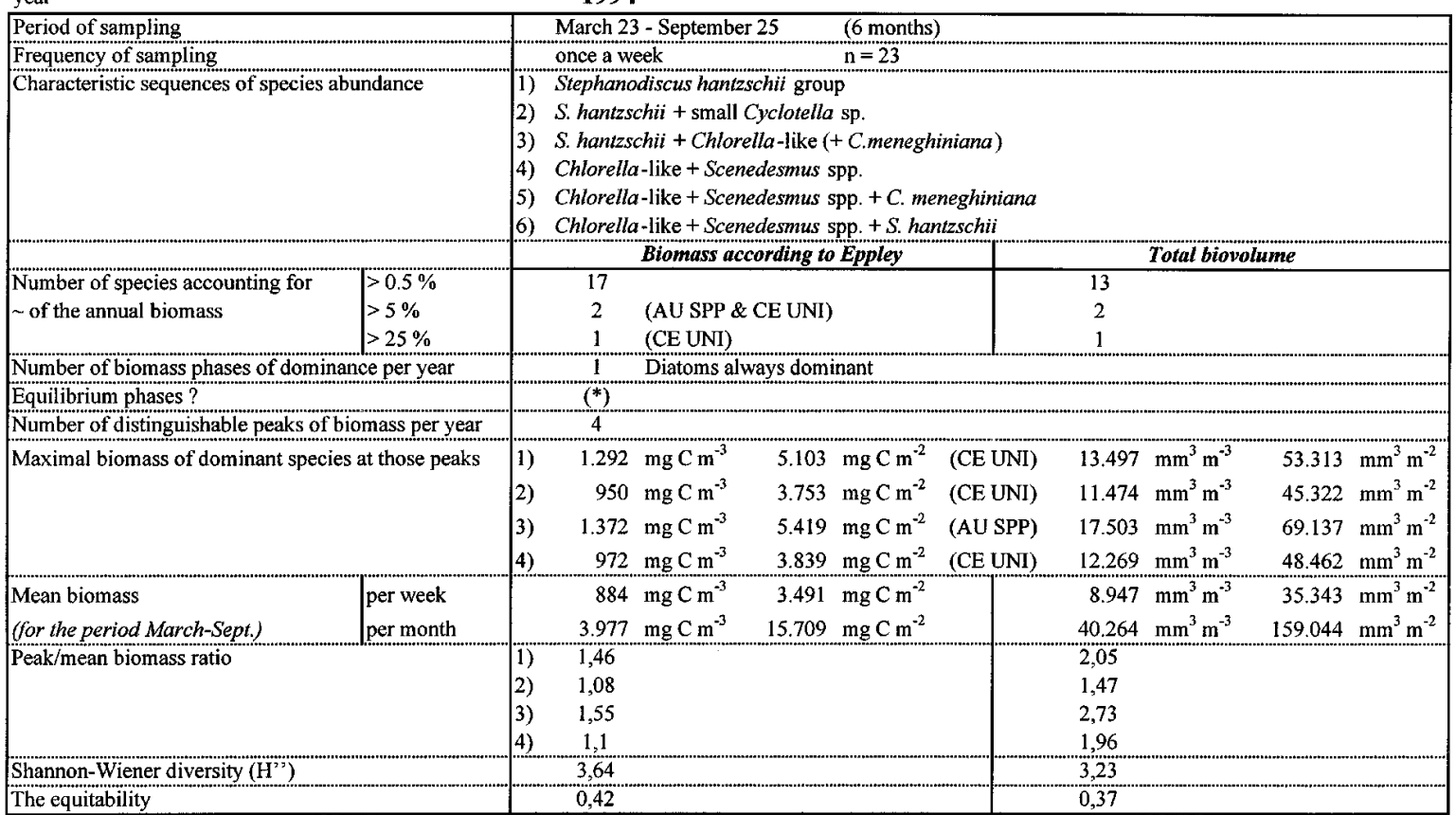

year

Period of sampling

Frequency of sampling Characteristic sequences of species abundance

Number of species accounting for $\sim$ of the annual biomass

Number of biomass phases of dominance per year Equilibrium phases?

Number of distinguishable peaks of biomass per year

Maximal biomass of dominant species at those peaks

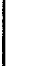

Mean biomass

(for the period March-Oct.)

Peak/mean biomass ratio

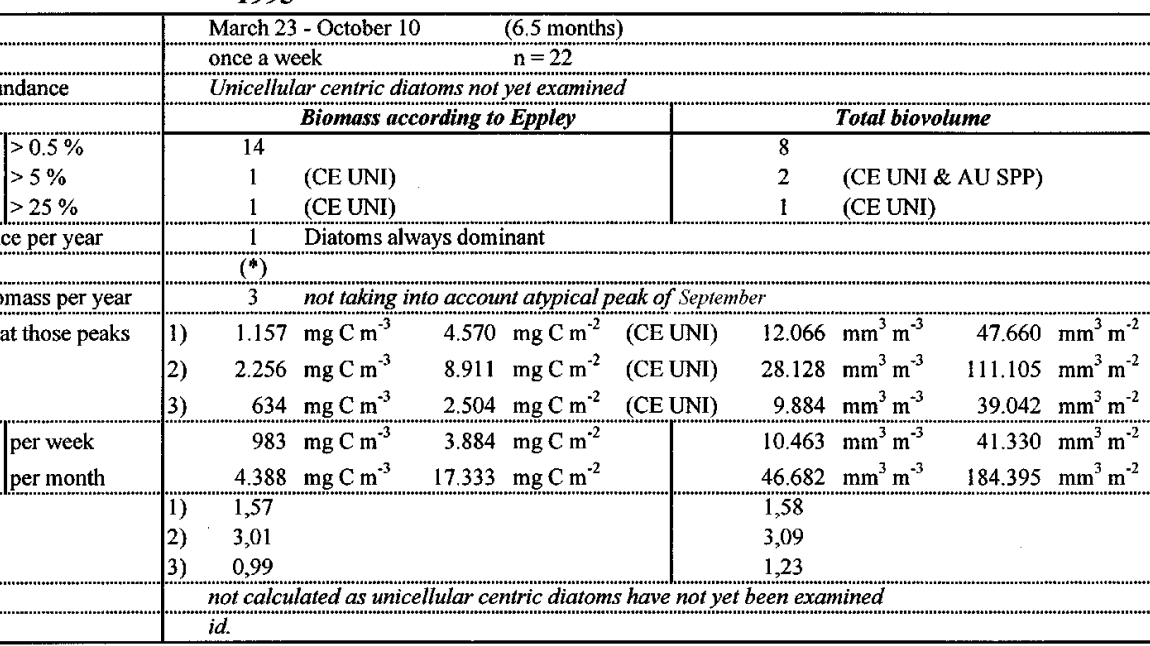

Shannon-Wiener diversity $\left(\mathrm{H}^{\prime \prime}\right)$

The equitability

1995

(*) As biomass was not calculated for each unicellular centric diatoms, we can not precisely distinguish equilibrium phases according to biomass. Nevertheless when $S$. hantzschit or $C$. meneghiniana are dominant in terms of abundance they are also in terms of biomass.

- CE UNI = unicellular centric diatoms; AU SPP = Aulacoseira spp 
Phytoplankton data (see material \& methods chapter for more explanations)

year

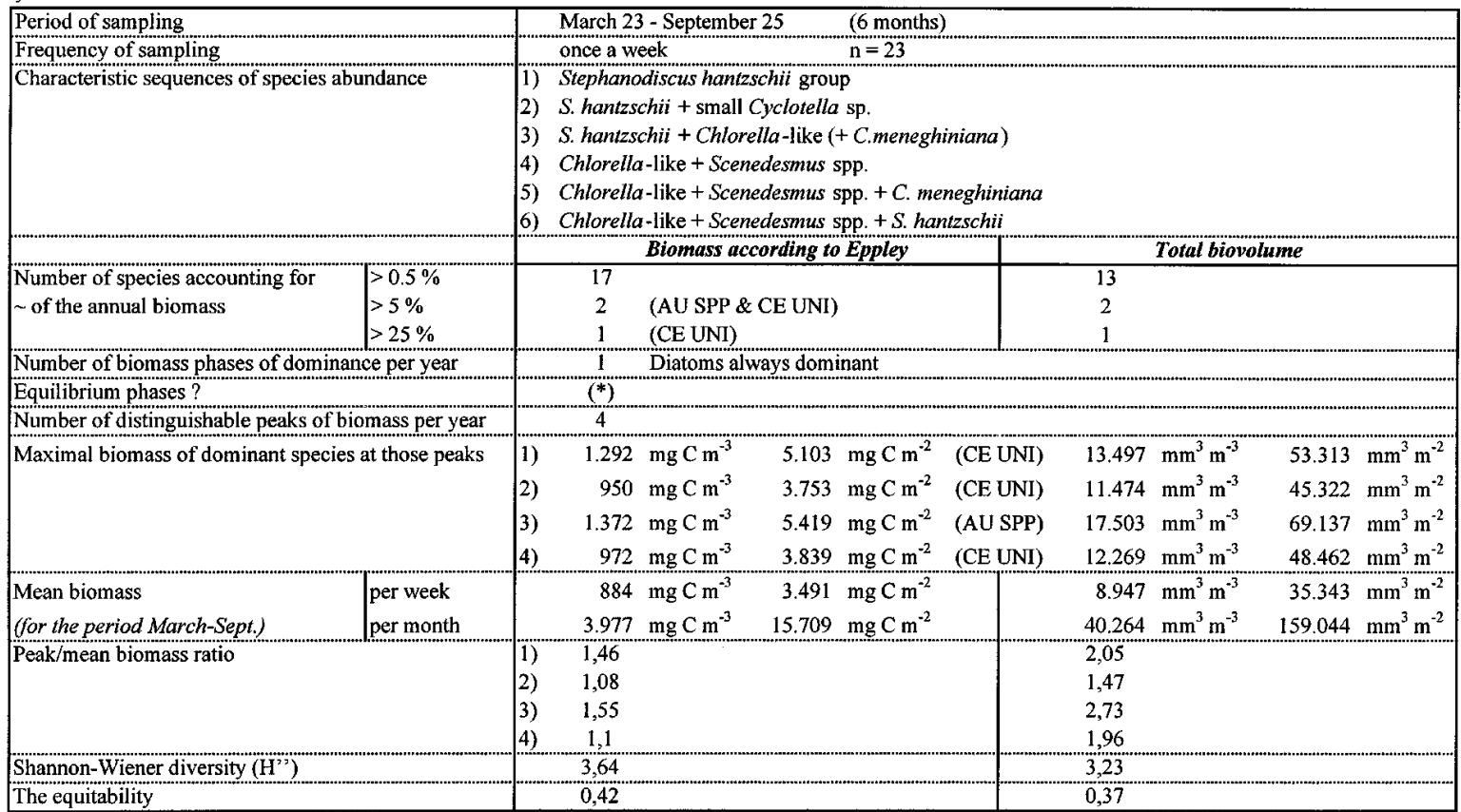

year

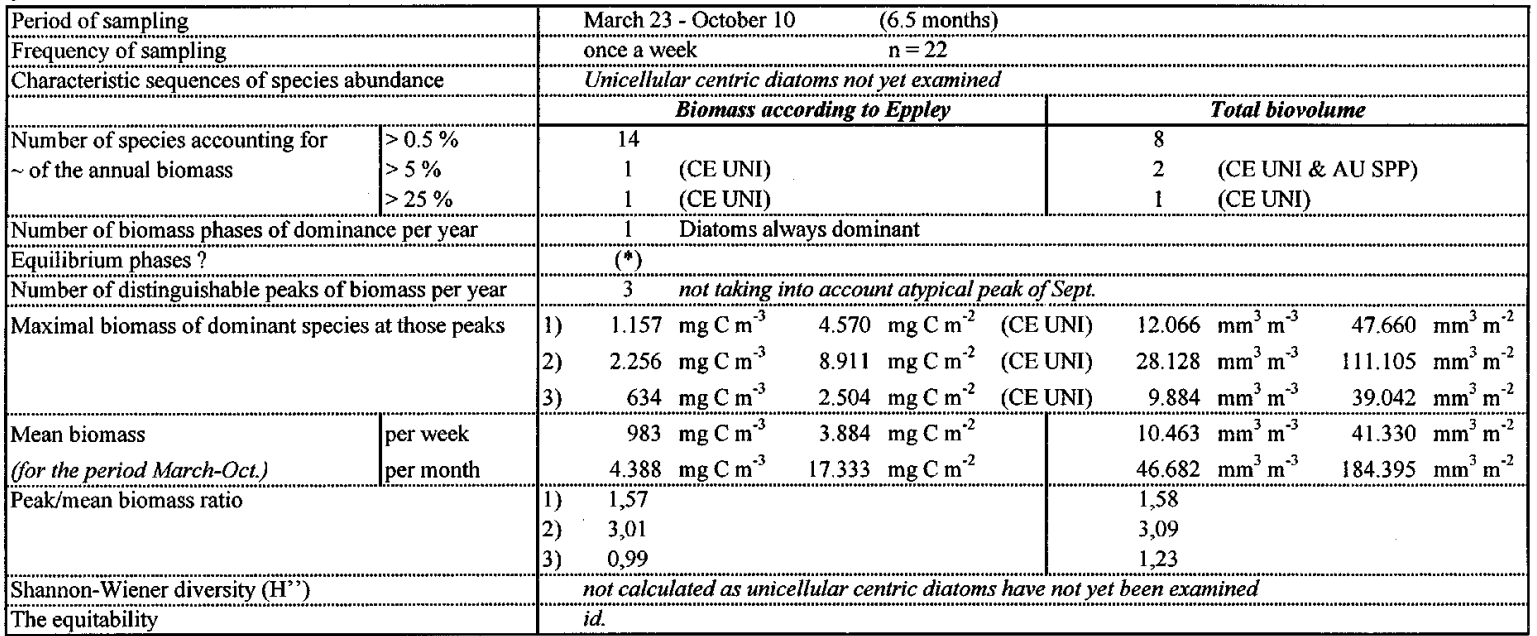

${ }^{*}$ ) As biomass was not calculated for each unicellular centric diatoms, we can not precisely distinguish equilibrium phases according to biomass. Nevertheless when $S$. hantzschit or C. meneghiniana are dominant in terms of abundance they are also in terms of biomass.

- CE UNI = unicellular centric diatoms; AU SPP = Aulacoseira spp. 

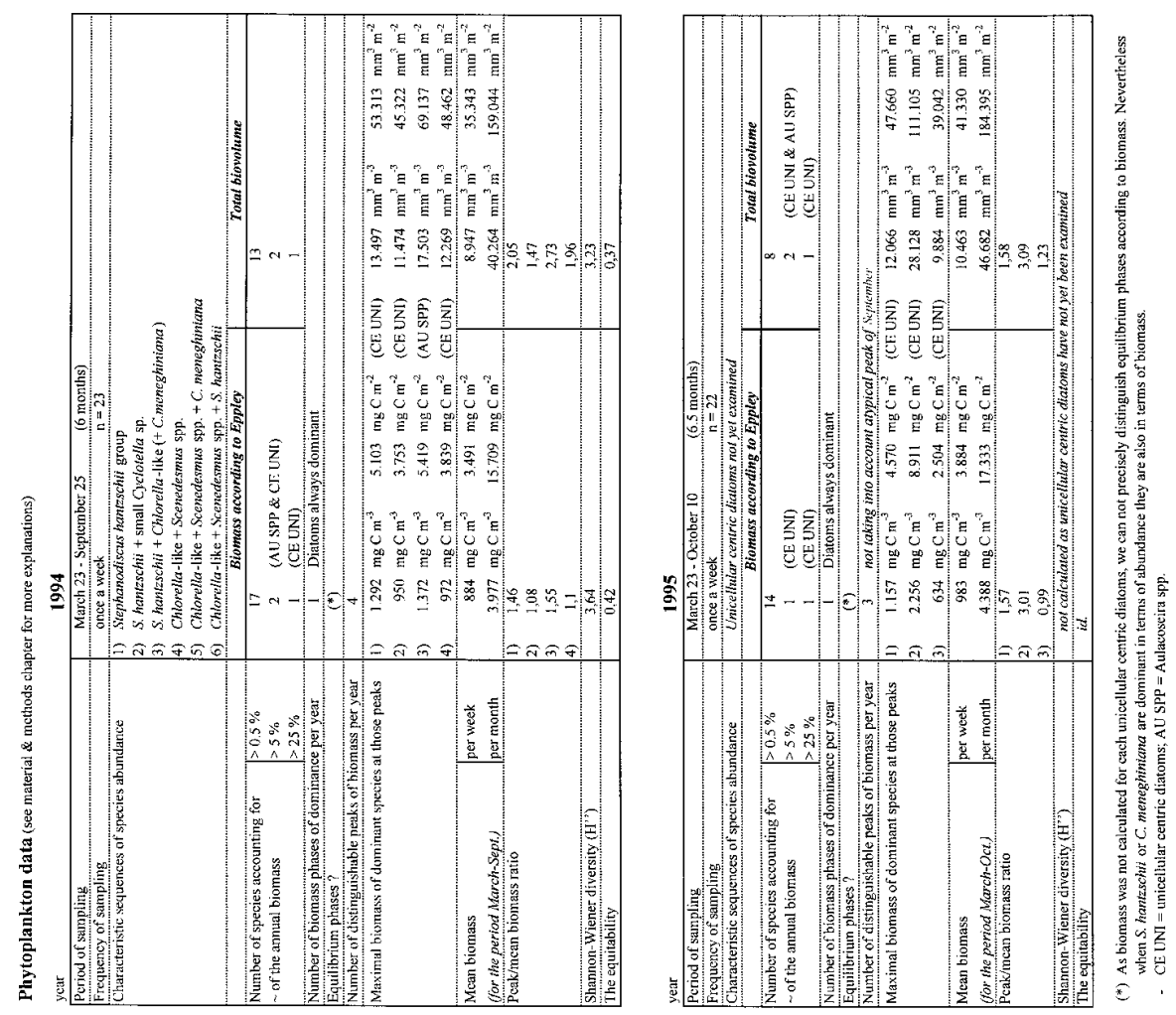